\title{
Notas para comprender las imágenes de la Lira Popular
}

\section{Notes to understand the Lira Popular's Images}

\author{
Tomás Cornejo \\ Instituto de Investigación en Ciencias Sociales, Universidad Diego Portales. \\ tomas.cornejo@mail.udp.cl
}

\section{Resumen}

Estudio del funcionamiento de las imágenes de la Lira Popular o literatura de cordel chilena. Se discute la relación entre el carácter narrativo de gran parte de los textos y las imágenes que, hechas a propósito para ilustrar o comentar dichos textos -frente a un público de competencias lectoras limitadas- llevan a pensar que ellas son eminentemente referenciales. A partir del desentrañamiento del origen de algunos de los modelos iconográficos de las xilografías, se las pone en relación con imágenes provenientes de la cultura oficial (retratos presidenciales), estableciendo el modo en que las imágenes características de la Lira Popular construyeron matrices gráficas para representar un gran abanico de tipos sociales, fácilmente reconocibles para el público urbano de la época.

Palabras clave: Lira Popular, literatura de cordel, cultura popular, xilografías, gráfica.

\section{Abstract}

Study about the images of the Chilean broadside literature, known as Lira Popular. The article discusses the relationship between the narrative character of most of the texts and the images, made on purpose to illustrate or comment on these texts -aimed at a mostly illiterate public-, that lead to conceive the images as eminently referential. Paying attention to the iconographic models of the woodcuts, however, they become related to images from official culture (presidential portraits), setting the mode in which most representative Lira Popular's images constructed a language made of graphic molds able to represent a wide range of social types, easily recognizable to urban audiences of the time.

Keywords: Lira Popular, Broadside Literature, Popular Culture, Woodcuts, Graphics. 


\section{Introducción}

Uno de los aspectos más descuidados en los estudios sobre la Lira Popular es el iconográfico. La atención dada a la riqueza literaria y al contenido político y social de los textos compuestos por los puetas se ha realizado, en parte, olvidando el carácter de artefacto impreso de los pliegos. Esto puede obstaculizar una mejor comprensión de cuáles fueron los modos en que los contemporáneos, así productores (poetas, impresores y grabadores) como usuarios (lectores, espectadores y auditores), se relacionaron con este objeto cultural.

Alamiro de Ávila Martel, bibliógrafo y forjador de una colección de pliegos de poesía callejera, fue uno de los primeros en interesarse por el estudio de las imágenes. Sobre los grabadores populares, indicó que "junto a la simplicidad a que obliga el material y una técnica rudimentaria, encontramos un verdadero alarde creador para cubrir superficies bastante extensas" (6). De acuerdo con el mismo autor, las imágenes habían sido realizadas con un gran talento interpretativo, habilitando la conformación de "un realismo mágico al que contribuye con frecuencia el acoplamiento de los temas” (6). Para Ávila Martel, la estética podía no responder a las exigencias estilísticas del público poseedor de un gusto cultivado académicamente, pero en cambio la congruencia entre tema y ejecución debía resaltarse. Por último, y expresándose asimismo desde un atalaya estético de aprecio por las vanguardias, el bibliógrafo se refirió a las imágenes presentes en los pliegos, aunque no hechas ex profeso con este fin, sino apropiadas de otras fuentes. "Estos elementos espúreos [sic]" -afirmó- "sirven admirablemente como detalles complementarios de la composición, dentro de una constante búsqueda tendiente a rellenar, efecto de un notorio odio al vacío, y que llegan a producir resultados extraordinarios de verdaderos collages" (6).

El profesor Pedro Millar volvería sobre el tema casi dos décadas después, centrando su interés en las imágenes xilográficas. A su juicio, estas se caracterizan por

un intenso estímulo perceptual generado por el empleo extremadamente austero de los recursos esenciales de la xilografía. El encadenamiento de las formas, los llenos y los vacíos por los contornos, que valoriza y conecta, rigurosamente, la figura y el fondo. El ritmo, que resuelve la antítesis de blancos y negros. En fin, la síntesis que compromete a una intensa participación al espectador (19).

En la interpretación esbozada por Millar, los pliegos eran un objeto gráfico que actualizaba contenidos y experiencias culturales en cierto modo atemporales, pertenecientes a un fondo común de creencias e imaginarios de sectores sociales subalternos de origen rural. La manifestación cultural de la Lira Popular habría de insertarse en un contexto como el Chile de fines del siglo xIx, donde "la cultura de los sectores marginales se desarrollaba dentro de sus propios márgenes, en forma endógena, sin resonancia con los otros estamentos de la sociedad" (18), aunque, según afirma a continuación, el propio desarrollo de la labor de puetas e impresores populares, "nos [revela] el carácter 
abierto de la cultura popular hacia hechos comunes al conjunto del cuerpo cultural de la nación" (18), en el cual la prensa periódica tuvo un papel preponderante.

Desde la estética, Patricio Rodríguez-Plaza ha cuestionado el carácter ingenuo atribuido a las imágenes de la Lira Popular, particularmente a sus grabados en madera. Ese encasillamiento, argumenta, está determinado por el olvido del resto de la iconografía que integra este universo gráfico. En conjunto, xilografías, grabados de diversa índole, clisés y fotograbados crean un "banco de estampas gráficas, sin el cual la literatura de cordel no hubiese adquirido la presencia dentro de los sectores entre los que existió" (91). Para aquilatar la recepción de tales impresos entre un público mayoritariamente iletrado, habría que atender a la primacía del componente visual por sobre el texto, en tanto "las imágenes reactualizaban anécdotas e historias, pero también es dable pensar que sus evocaciones eran producciones contundentes de imaginarios que sólo con la imagen visual adquirían la tenacidad necesaria” (91).

Para Rodríguez-Plaza, comprender las imágenes es preciso por cuanto eran estas las que intervenían en el espacio público de las ciudades chilenas del cambio de siglo. Atrapando la atención y la mirada de las clases trabajadoras, las llevaban a "imaginar con rasgos visibles algo que no se tiene inmediatamente a la vista", en virtud de la existencia, en la cultura popular, "de matrices simbólicas conectadas [...] a sensibilidades e imaginarios alimentados por diversas redes que atan este mundo a la realidad" (93).

Un acercamiento más reciente a este problema ha efectuado la historiadora del arte Carolina Tapia. Luego de varios años de investigación sobre las diversas colecciones de pliegos, Tapia pudo establecer los rasgos más señeros de su contenido iconográfico. En lo que toca a las xilografías, destaca los trazos gruesos y rígidos, la composición carente de perspectiva y la construcción de figuras con una proporción no habitual. Todo ello, plantea,

es producto directo de la dificultad de la madera y las herramientas empleadas para su tallado. Es prácticamente la técnica la que se expresa [...] supeditando a la forma, por lo tanto las figuras tienden a ser más esquemáticas que naturalistas. Por ello, también, es factible cualificar al conjunto de estampas como una expresión unitaria, aun cuando se puedan distinguir en ellas diferentes "manos" (85).

La autora llama la atención sobre el aspecto comunicativo de la Lira Popular. La función de grabados y xilografías en particular fue alentar "la participación del espectador en el sentido de provocar en él una reacción [...]. Hace más de cien años, los grabados populares eran parte importante del mensaje del pliego en sí mismo" (91), el cual se hacía efectivo enfatizando "el qué sucedió, genéricamente, por sobre el cómo sucedió. Por lo tanto, en [ellos] no se busca el naturalismo ni la exactitud de la representación, sino tan solo evocar de la manera más directa el hecho narrado" (87).

El único estudio sistemático respecto al contenido visual de la Lira Popular es un libro de muy reciente aparición, cuya autora, Simoné Malacchini, se acerca al tema desde el diseño gráfico. Ello indica cuán necesario es continuar ahondando sobre el 
particular, pero asimismo el gran interés que despierta la poesía popular impresa en nuevas generaciones de investigadores premunidos de lenguajes disciplinares variados (xvi Seminario sobre Patrimonio Cultural).

La interrogante central de Malacchini refiere al problema de la identidad: "por qué se la percibiría [a la Lira Popular] como soporte de identidad chilena desde donde se vincularía su visualidad a una iconografía 'propia"' (76). Determinadas filiaciones y genealogías del desarrollo artístico chileno del siglo xx fueron, según la autora, las que propiciaron tal concepción, pese a que su trabajo deja de manifiesto que "la mayoría de los elementos que conforman la visualidad de la Lira Popular son de origen foráneo” (158).

Con el fin de aclarar esa contradicción aparente, en que un proceso de apropiación cultural cobró forma a fines del siglo XIx, bien vale seguir la disección gráfica expuesta por Malacchini (91-150). Se comprueba de tal forma cómo los pliegos chilenos tomaron herramientas de los modelos impresos más legitimados en la época (incluidos los libros) pero en especial las publicaciones periódicas, con las cuales el público nacional de toda condición estaba familiarizado. Los productores de la Lira Popular alcanzaron una efectividad comunicativa envidiable al echar mano de recursos como la jerarquización de contenidos textuales (incluidos los títulos), una diagramación repetida y estandarizada (de fácil reconocimiento), las mismas tipografías de impresos de amplia divulgación y, por supuesto, un conjunto heterogéneo de iconografías.

Con este campo apenas desbrozado, el propósito de este artículo es analizar las imágenes de los pliegos de poesía chilenos y establecer su funcionamiento en tanto lenguaje visual propio, si bien no autónomo respecto de otras formas de iconografía contemporánea. Al contrario, se volverá manifiesta la integración profunda con un registro más variado de materiales gráficos, factor crucial que permitió a la Lira Popular constituirse en un actor destacado de la cultura popular chilena. Como elemento central resalta, en tal sentido, la tensión entre referencialidad e iconicidad de los grabados en madera dentro del proceso comunicativo de los mismos. Este tipo de grabado, de gran belleza y alta expresividad, y que se ha vuelto representativo de esta modalidad cultural, surgió de un proceso creativo bastante elaborado. En efecto, la aparente simplicidad de las imágenes xilográficas -su pretendida inocencia-, propia de una total economía de medios, fue una estética manufacturada en diálogo con un modelo iconográfico de fuerte preponderancia a fines del siglo xix, el cual fue estilizado y reelaborado desde una coordenada sociocultural opuesta.

\section{Textos e imágenes: cultura visual impresa en el Chile de fin de siglo}

Los testimonios de la época, entre los cuales sobresale el estudio de Rodolfo Lenz, indican que el consumo cultural de las hojas sueltas o pliegos de poesía era bastante complejo. Se acercaba a la oralidad, en tanto algunos de sus versos eran cantados en chinganas y otros lugares de sociabilidad popular (542). El origen mismo de algunas 
composiciones era la tradición oral (remontándose incluso a romances ibéricos), al igual que el carácter dual de pueta y cantor de algunos de los propios compositores de los textos (Acevedo Hernández 13-22). Todo ello se corresponde con los altos grados de analfabetismo de la población, que en Santiago rondaba el 57\% del total de habitantes en 1885, frente a guarismos bastante más altos en provincias, según la Oficina Central de Estadística (187), agregándose una gran brecha entre las clases trabajadoras y la élite letrada.

A lo largo de la segunda mitad del siglo xIx, por otra parte, hubo un constante crecimiento de los niveles de alfabetización, producto de políticas culturales públicas que beneficiaron a los grupos sociales medios. Se generó al mismo tiempo un mercado editorial más variado y -no menos importante- un segmento significativo de las clases trabajadoras adquirió competencias lectoescritoras y se vinculó con los medios impresos, al igual que la generalidad de la población del país (Subercaseaux 120-5). Prueba de ello es el aumento sostenido de publicaciones periódicas y libros, así como la generación de un mercado editorial en Santiago y Valparaíso, pero también en urbes de menor tamaño y regiones de expansión geográfica reciente, como el norte salitrero (Ossandón y Santa Cruz 2001 y 2005). Con todo, el desarrollo de la habilidad lectora es solo una parte del entramado cultural en relación con los soportes impresos, pues en su recepción hay elementos adicionales en juego. En América Latina, Montserrat Galí Boadella demostró que el uso de imágenes ha sido fundamental, al volver más permeable la frontera entre oralidad y escritura (93-6).

En otras latitudes hubo procesos semejantes, cuyo estudio puede arrojar ideas iluminadoras para nuestro análisis. Patricia Anderson postula que, en la Inglaterra de las primeras décadas del siglo xıx, la ampliación del universo iconográfico constituyó un reordenamiento cultural (140-56). Una creciente disposición de imágenes presentes en publicaciones de muy diversa índole y dirigidas a un público más vasto rompió el monopolio de las élites sobre los objetos visuales de cierta calidad estética. Esto implicó que, en el ámbito urbano, sujetos con trasfondos sociales distintos participasen como consumidores o receptores de unos mismos objetos culturales. En estos impresos que aunaban texto e imágenes, estas últimas se convirtieron en un punto de encuentro entre sectores sociales, dados sus diferentes grados de alfabetización y conocimiento artístico. En torno a tales imágenes, en definitiva, comenzaron a formarse unos patrones culturales interclasistas, plenos de tensión y conflicto, definidos no tanto por los soportes materiales, como por el uso y la significación que les dieron sus receptores, moldeados por experiencias sociales, culturales y aun regionales diversas.

Con respecto a la visualidad de la Lira Popular, enfaticemos que esta no se colmaba únicamente con materiales "populares", ni era autónoma en sus motivos. Por el contrario, los pliegos denotan que sus creadores se relacionaron con una cultura y un mercado gráfico mayores (Álvarez Caselli 74). En este último participaban, además de pequeños talleres tipográficos donde se fabricaban generalmente los pliegos en cuestión, el Estado y empresarios privados de más o menos recursos (Soto Veragua 90). 
En el Chile de la segunda mitad del siglo xix, la unión de texto e imagen proliferó, por una parte, en los libros. Algunos fueron proyectos editoriales oficiales, patrocinados o encomendados por el gobierno y destinados a una circulación restringida entre sus propios personeros o bien concebidos para fomentar la publicidad del país en el extranjero, como la Galería nacional de Narciso Desmadryl, 1854; el Chile Ilustrado de Recaredo Tornero, 1872; y el Chile en 1910 de Eduardo Poirier, 1910.

En el ámbito de la prensa, cuyo espectro de receptores era más variado y amplio socialmente, la incorporación de imágenes fue más tardía, pero mucho más penetrante. Estas gozaron de un uso y repercusión mayores en la prensa satírica, que desde 1858 comenzó a publicar caricaturas. Su eclosión se produjo entre finales de la Guerra del Pacífico y 1895, gracias a la creativa iniciativa del periodista y escritor Juan Rafael Allende, quien tuvo muchos imitadores y rivales (Salinas et al. 2001; Salinas, Cornejo y Saldaña 2005). La llamada "prensa seria", por el contrario, fue reacia a la inclusión de imágenes, con excepción de las que integraban los avisos comerciales. La irrupción definitiva de una iconografía más elaborada y constante en los periódicos se produjo con la aparición del santiaguino El Diario Ilustrado, que desde 1902 utilizó fotografías de manera sistemática. Hasta ese momento, dicho tipo de imágenes, así como las litográficas, estuvo restringida a unas pocas publicaciones especializadas o magazinescas, de circulación mucho más acotada -entre otras, La Ilustración, Santiago, 1899-1905-, o se ensayó en periódicos con llegada a un amplio público urbano, que cubría varios estratos sociales -como El Chileno-, abandonada sin embargo a los pocos meses.

La Lira Popular se nutrió de todas estas fuentes de material iconográfico. La heterogeneidad del universo que compone la visualidad de los pliegos de poesía es, en efecto, vasta: grabados en madera, litografías "populares" (en el sentido de no académicas) y académicas, fotografías y clisés de imprenta. Esto se debió, en buena medida, a que algunos cultores de la poesía popular contaron con imprentas propias, pequeños talleres tipográficos con los recursos mínimos para sus labores, cuestión observable en numerosos pliegos confeccionados con tipos muy gastados y en un papel de muy mala calidad, los que contienen varios errores en la composición de los textos y la disposición de las imágenes. Entre ellos se encuentran Juan Bautista Peralta, Nicasio García y Juan Ramón González, quienes desde pequeños tuvieron contacto con el mundo editorial, como suplementeros, aprendices de imprenta y finalmente autores y fabricantes de sus propios pliegos -en el caso de Peralta, con algo más de fortuna en el negocio (Atria 72-3; Cornejo 31). En más de una ocasión los puetas estamparon anuncios de los servicios ofrecidos por los establecimientos tipográficos con los cuales tenían vínculos más estrechos:

IMPRENTA ERCILLA (Bandera 21-K, entre Santo Domingo y Catedral) hace á precios baratísimos: Esquelas de defunción, Carteles, Cuentas, recibos, circulares, tarjetas Comerciales, de visita, de matrimonio, de bautizo, etc., etc. Recibos para conventillos ó casas á Un peso el libro de 100 hojas con talones. Utiles de escritorio. (En Juan Historia [seud.], Col. Am., III, 610). 
Pero los pliegos también fueron confeccionados por casas reputadas, como la imprenta de El Mercurio y la Litografía Leblanc, según consta en los datos que buena parte de ellos consiga. Esta última casa editora contaba con muchos adelantos en materia de impresión de imágenes. Sobre el aspecto técnico, según informa Álvarez Caselli, el fotograbado fue introducido en el país en 1892 y hacia 1900 ya había varios talleres tipográficos utilizándolo. Antes de su difusión se había vuelto más común la cincografía (72). Como sea, resalta la gran adaptabilidad de los impresores de la Lira Popular frente a las innovaciones tecnológicas, rasgo no privativo de nuestro país, documentado asimismo en el México contemporáneo (Gretton 125-42).

Una incógnita que subsiste es determinar qué proceso seguían algunas imprentas que, como las mencionadas, se encargaban asimismo de la elaboración de los productos culturales de la élite y las clases medias santiaguinas; entre otros, los periódicos que se leían en su seno y los costosos volúmenes que adornaban sus bibliotecas. Algunas imágenes aparecen en uno y otro producto de estas imprentas. Es posible rastrear, por ejemplo, las primeras fotografías publicadas por El Chileno entre 1902 y 1903 en pliegos de Juan Bautista Peralta, colaborador eventual del matutino (figs. 1 y 2 ).

En cuanto a la proveniencia de las imágenes, los grabados en madera hoy considerados más típicos de la Lira fueron, presumiblemente, realizados ex profeso para determinadas hojas. El resto de la iconografía corresponde a reutilizaciones de materiales destinados a otros fines: caricaturas de publicaciones satíricas, ilustraciones de corte romántico de magazines, retratos aparecidos antes en libros y en periódicos, así como un sinnúmero de imágenes cuyo origen es imposible de determinar. Es probable que sean clisés importados por algunas imprentas de mayores recursos que los descartaban de sus materiales de trabajo (Álvarez Caselli 66). Un dato ilustrativo puede ser el aviso de Luz y Reflejos de la segunda semana de marzo de 1905, revista patrocinada por la Sociedad Unión de los Tipógrafos: "Oportunidad. Se vende los clisées [sic] que ilustran esta Revista, a medida que se van publicando, al módico precio de 2 centavos el centímetro cuadrado. Hay disponibles vistas de Chile i de la guerra Ruso-Japonesa. De su excelente estado de conservación dan testimonio las ilustraciones de nuestra publicación" (64). En otras ocasiones, cuando corresponde a grabados con mayor elaboración, se advierte a veces una firma, tal vez de artistas españoles o franceses.

De esta manera, aun cuando la percepción común que tenemos respecto a la Lira Popular se asocia en exclusiva a las xilografías (de ahí la tendencia a acentuar justamente el carácter "popular" de esta manifestación cultural), concordamos con la idea de Rodríguez-Plaza ya citada, respecto a cuán fundamental es recordar que estas formaban parte de un entramado mayor (fig. 3).

Esto generó no pocas contrariedades a los actores del circuito cultural impreso chileno. El 2 de julio de 1892, el fugaz semanario ilustrado Los sucesos del día, editado en la capital, señaló indignado: 


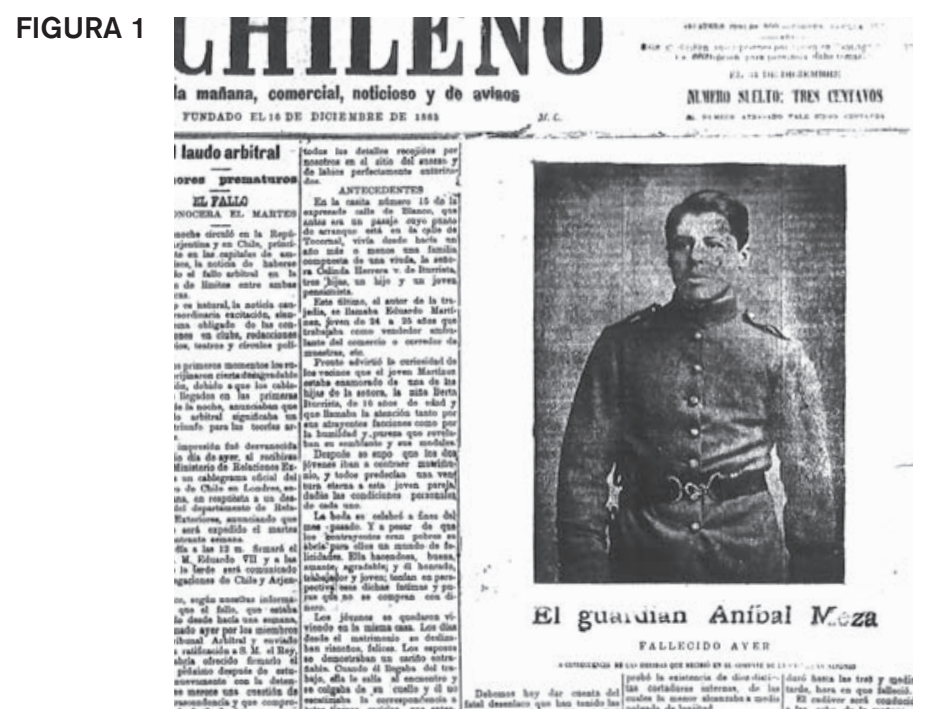

FIGURA 2

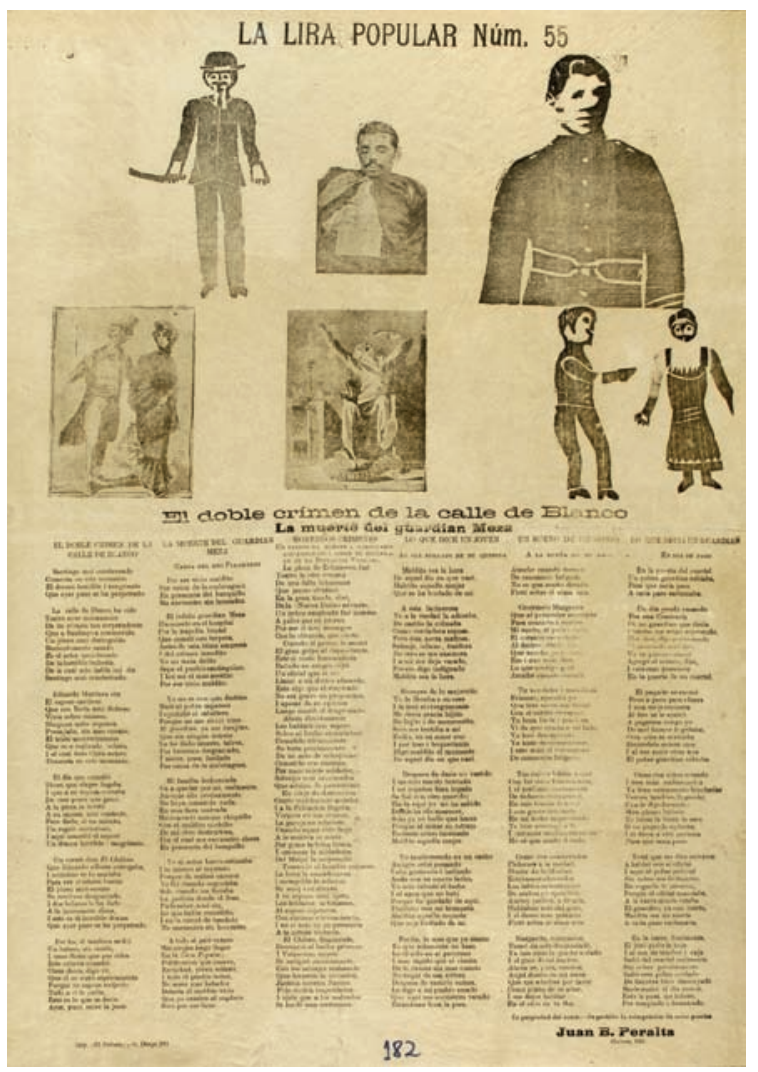

Apropiación de un fotograbado de El Chileno (“El guardián Aníbal Meza fallecido ayer”, 23/11/1902, p. 1), invertido lateralmente en un pliego de Juan Bautista Peralta (abajo), para ilustrar el texto $E l$ doble crimen de la calle de Blanco - La muerte del guardián Meza, Col. A.A., 182. 
FIGURA 3
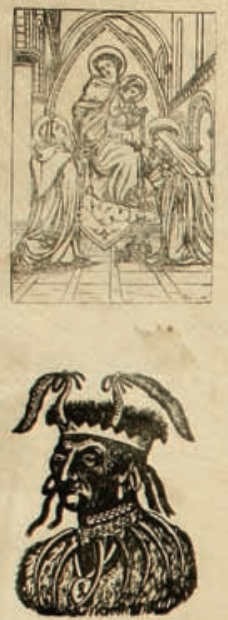
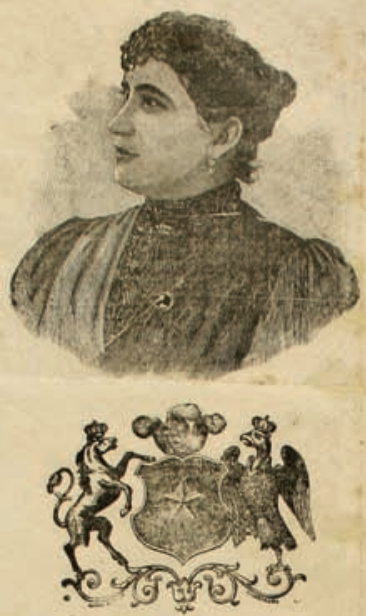
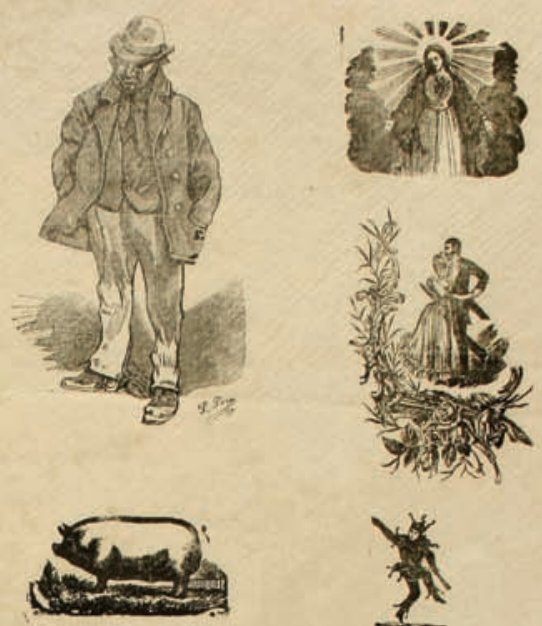

DRAMA SALVAJE

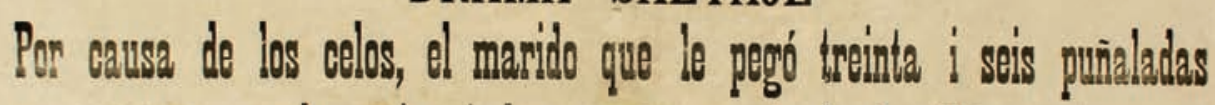
a la mujer $i$ despeses de muerta la degollo

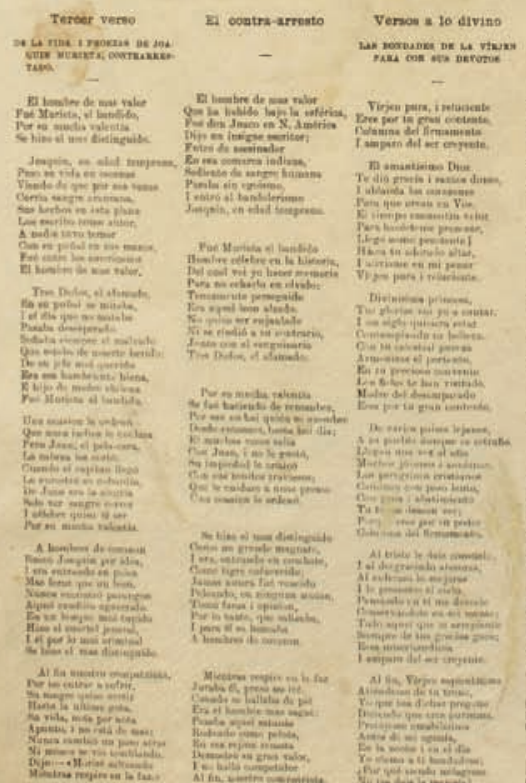

$\frac{1}{1 m 0 .}$ Moiecta 843

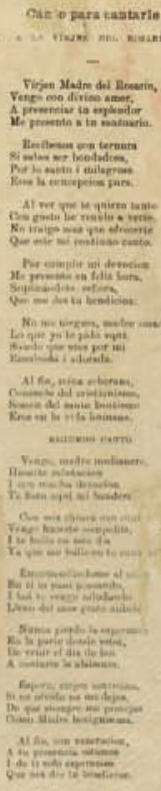

84

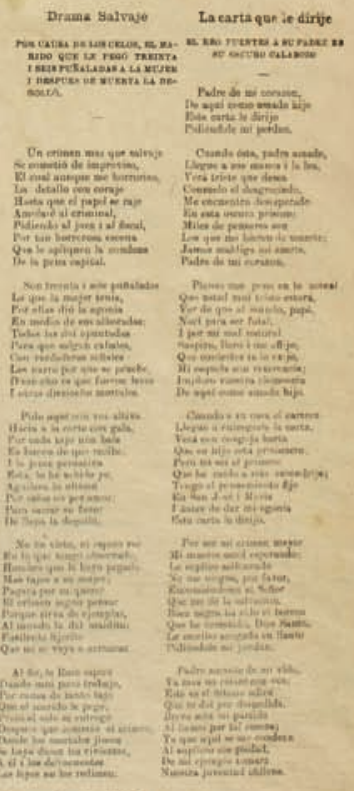

Daniel Meneses.

Pliego completo de Daniel Meneses, Col. A. A., 84. 


\begin{abstract}
Una hoja suelta que circuló ayer con el título de 'El crimen de San Juan', ademas de estar impresa sin designar el taller tipográfico donde se confeccionó (lo que hacemos notar al señor intendente de la provincia), contiene un grabado que es un plajio de lo mas burdo que puede hacerse, del cuadro que en el primer número de nuestro semanario lleva por título 'Crimen de Pirque (el asalto)'. Esperamos que para otra ocasion, los autores de la hoja mentada, guardarán mas miramiento por las leyes que garantizan la propiedad artística (1).
\end{abstract}

Dicha recomendación no fue acogida, a juzgar por la continuidad de ese gesto de apropiación de las imágenes, gesto que redunda en una recontextualización total de ellas y, por tanto, de su significado inmediato y de su sentido en el conjunto del repertorio gráfico de los pliegos de poesía (figs. 4 y 5 ).

Un factor adicional a considerar es la difusión de la técnica xilográfica en Chile, de la cual se cuenta con poca información. El Chileno informó el 28 de junio de 1888 que en Santiago se instaló una escuela de grabado a cargo del maestro alemán Otto Lebe, contratado por el gobierno aprovechando el auge de los talleres tipográficos (2). El 16 de octubre de 1894, el vespertino La Nueva República, por su parte, dio cuenta de haberse discutido si dicha escuela debía seguir dependiendo de la sección de Bellas Artes o pasar al Ministerio de Industria (2). El 2 de febrero de 1896, el semanario especializado El Artesano informaba que la escuela en cuestión ya rendía frutos: "Hoy ya se principia a recibir en nuestras imprentas algunos grabados ejecutados por aventajados alumnos, salidos de este establecimiento de educación material, y no está lejano el día en que se generalice las publicaciones ilustradas entre nosotros" (14).

El grabado en madera tuvo un estatus ambiguo en el país, a medio camino entre las bellas artes sancionadas académicamente y la artesanía o aun la manufactura de un oficio arraigado en el aprendizaje práctico y con una vertiente de aplicación comercial e industrial (Berríos et al. 135-41). La xilografía, además, estaba ligada a los cambios que durante el siglo XIX sufrió el campo de la impresión, y que tuvieron a la fotografía como punto de llegada (Arias 22). Esto último es importante si se considera los procedimientos para imprimir imágenes en tirajes considerables y a bajo costo, amén de su reutilización, como fue el caso de la Lira Popular. Según un aviso de La Nueva República del 5 de enero de 1894, en Santiago funcionaba, entre otros talleres, el de Fernando Payá, situado en calle Esmeralda (cerca del Mercado Central y próximo al Mapocho, barrio donde habitaban algunos puetas renombrados), que ofrecía "grabados en madera i fotocincografia en toda clase de dibujos. Se ilustran toda clase de obras literarias. Precios convencionales" (3).

Los trayectos entre la enseñanza artística formal y la forja de un arte gráfico popular, cuyos radios de acción no necesariamente convergen, pueden apenas entreverse. Los ejecutantes del material gráfico más representativo de la Lira Popular han quedado en la penumbra. Se sabe que en ocasiones algunos de los propios puetas ejecutaban los grabados; de acuerdo con Lenz (574), Adolfo Reyes fue uno de ellos, mientras que 
FIGURA 4

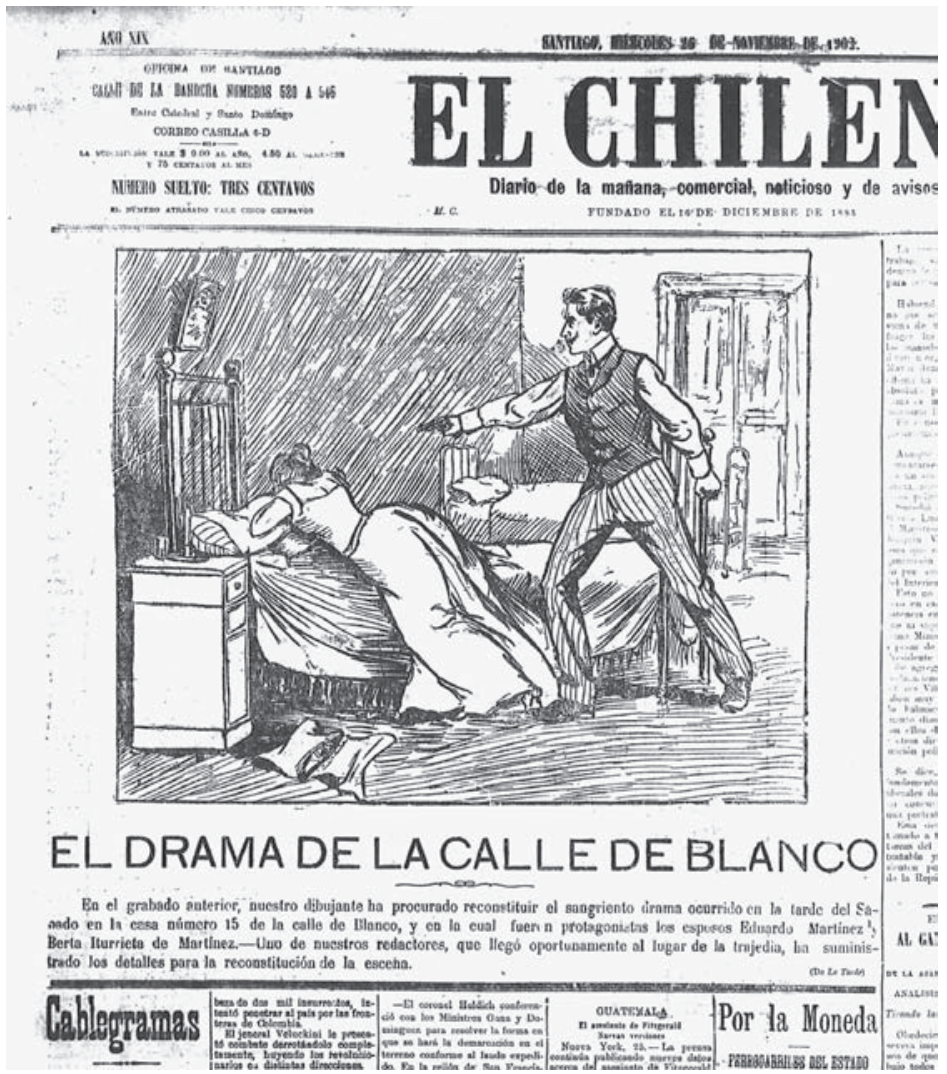

FIGURA 5

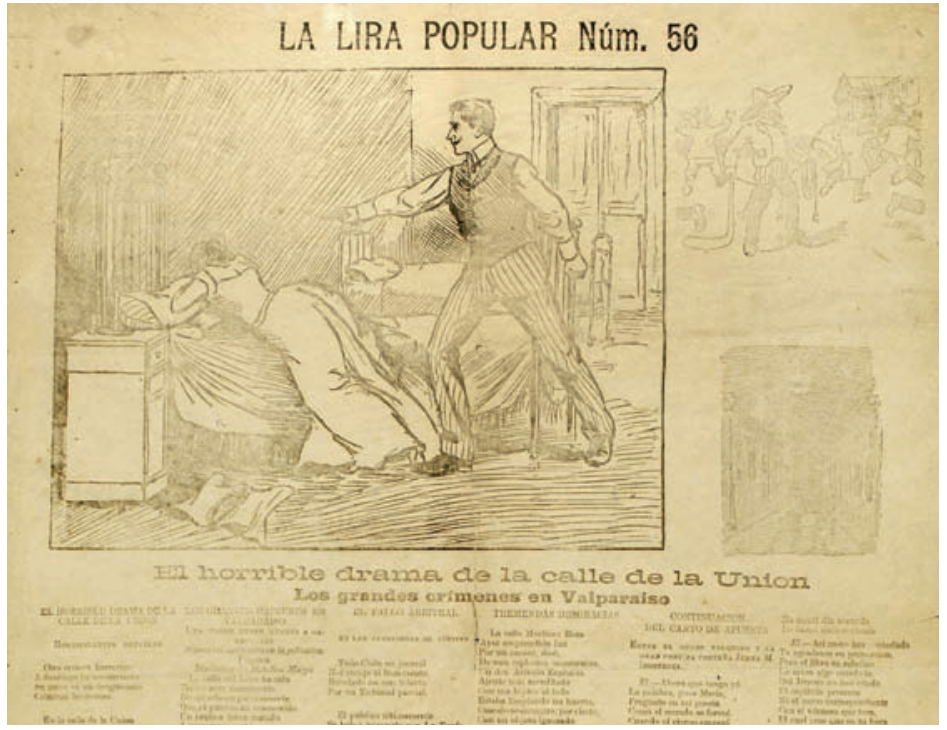

Arriba: grabado original de El Chileno, 26/11/1902, p. 1, utilizado con posterioridad en un pliego de Juan Bautista Peralta (abajo; Col. A. A., 183), para acompañar un texto sobre otro crimen. 
Jorge Octavio Atria se refirió a otro con igual habilidad, pero no dio su nombre (142). Según el lingüista alemán, dichos grabados eran "casi siempre increiblemente toscos" y por lo general se referían a "una 'trajedia', un asesinato, una ejecución de criminales, un accidente i otros asuntos sensacionales" (574). Lenz añadió un dato crucial: "Tales grabados orijinales se fabrican sólo por encargo especial de los poetas, quienes pagan por ellos dos a tres pesos i los guardan como propiedad suya para volver a usarlos en otras ocasiones más o menos propicias" (575).

De aquí se constata que las xilografías tenían un propósito inmediato: ilustrar o reforzar visualmente el contenido -generalmente, narrativo- de alguno de los textos del pliego, muchos de los cuales glosaban noticias tomadas de los periódicos (Orellana 63-82). Considerada como unidad cerrada, una composición individual relataba un "hecho de sensación" y para ello precisaba un correlato iconográfico salido de las manos de un artesano. Por tal motivo, en algunos casos la relación entre un grabado popular en madera y el contenido de determinados textos es evidente, ya que la carga referencial de la imagen da cuenta incluso de ciertos detalles presentes en los versos.

Sin embargo, aquello sucedía en una situación particular, cuando la xilografía era hecha a pedido y para una ocasión puntual. Como bien notó Lenz, los puetas no desechaban los tacos de madera con la matriz de la imagen, sino que los reutilizaban una y otra vez, haciéndoles en ocasiones pequeñas modificaciones para adaptarlos a la contingencia y las necesidades del momento. Así, muchos de los crímenes relatados llevan un mismo grabado, pese a que este no corresponda a las características, los oficios o el sexo de los personajes involucrados. Algo parecido ocurre con los demás temas objeto de los versos, pues se observa una alta repetición de imágenes con textos referidos a fusilamientos.

Los observadores contemporáneos advertían que -al menos para sus cánones ilustrados- la relación entre texto e imagen era arbitraria o antojadiza. Para nuestros ojos también puede serlo en un primer momento, sobre todo cuando se trata de pliegos que incorporan clisés de imprenta. En muchas hojas estos parecen haberse usado solo como adorno o bien para completar con un objeto llamativo un espacio en blanco de la superficie destinada a contener las imágenes, cuya profusión facilitaba tal vez la venta.

Un problema derivado es la intención comunicativa particular de las xilografías, dada su relación complementaria con los textos. Estas parecen cumplir una función narrativa, para lo cual apelan a un lenguaje figurativo y altamente referencial. Tal lenguaje, sin embargo, se construyó de manera algo paradójica. Con gran economía de medios, puetas, grabadores e impresores crearon un lenguaje visual tendiente a la iconicidad, a la pérdida de contenidos referenciales, supeditados al uso de un conjunto limitado de recursos gráficos que, en la forma de matrices movibles e intercambiables (figs. 6 y 7), permitieron narrar el universo social y político del país. El trayecto hacia ese lenguaje artístico se dio en contacto con los otros cánones visuales entonces disponibles, cuestión patente en las xilografías que representan a los presidentes de Chile, cuyos rostros y perfiles se multiplicaron en el espacio público del último cuarto del siglo xIX. 
FIGURA 6

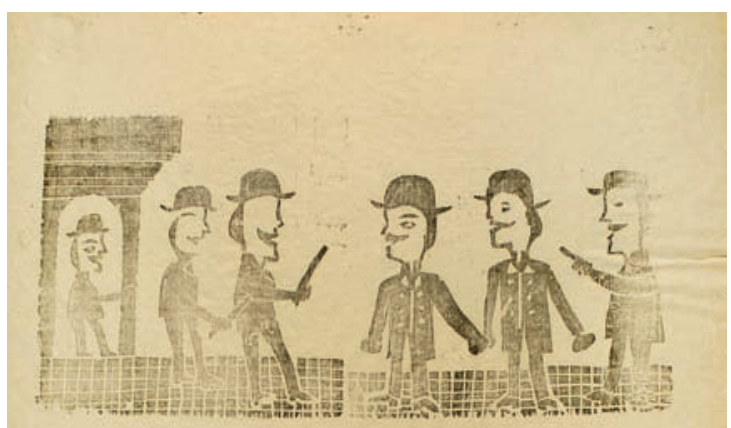

La Lira Pop̣ular - Núm. 24

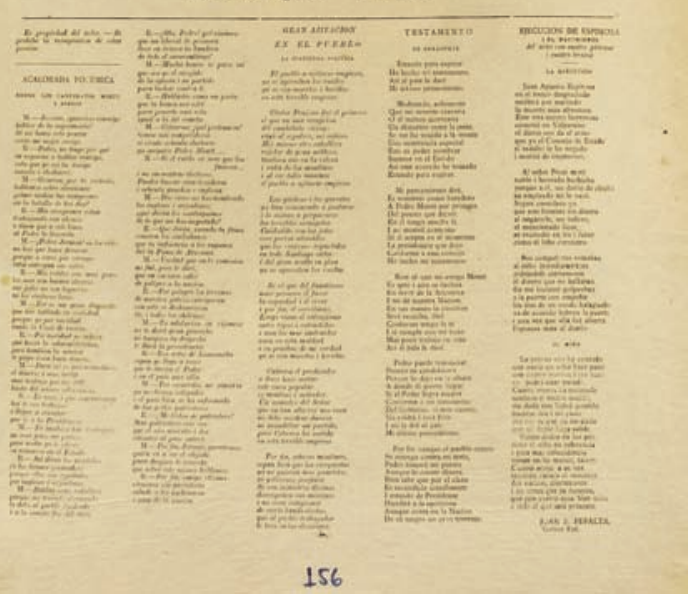

FIGURA 7

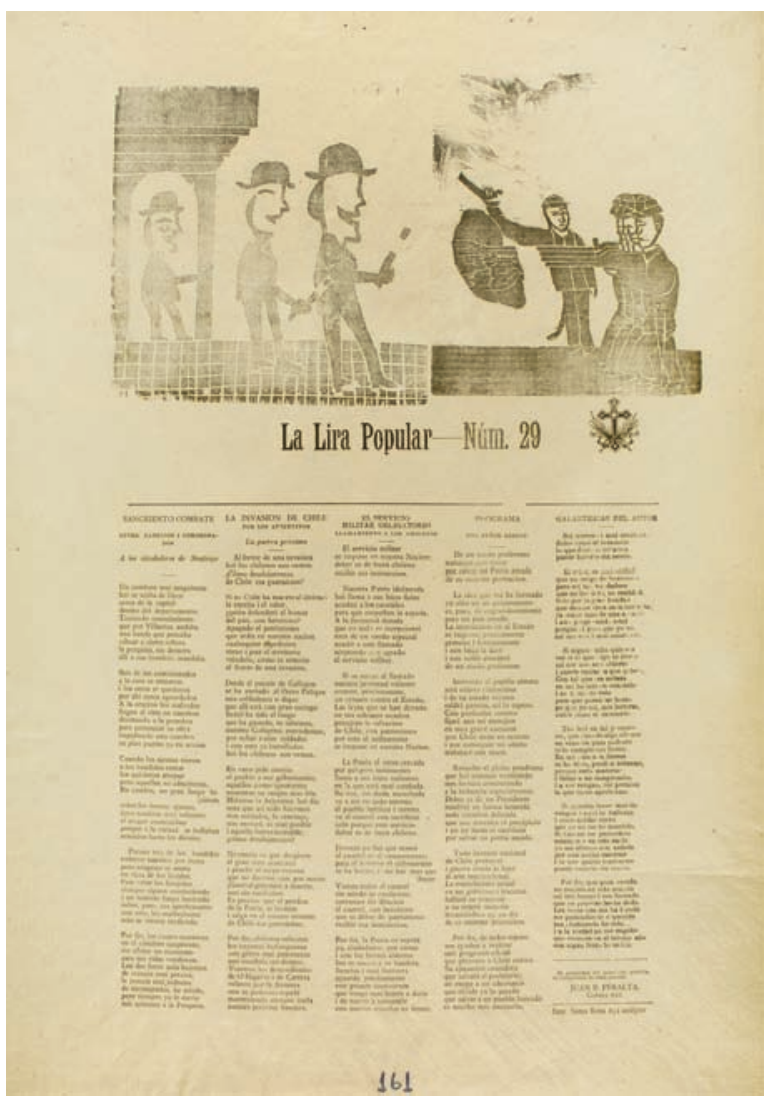

Montaje entre dos xilografías en dos pliegos diferentes, la primera para la composición Gran ajitación en el pueblo. La contienda politica, Col. A. A., 156, 1901; la segunda, para Sangriento combate entre bandidos i comisionados a los alrededores de Santiago, Col. A. A., $161,1901$.

\section{Una versión plebeya del retrato burgués: los presidentes en manos de los grabadores populares}

La fuente original de las efigies de los presidentes proviene de los retratos oficiales, en que aparecen ataviados sobriamente y con la banda presidencial tricolor terciada sobre el pecho como distintivo. Para inmortalizar sus rasgos fueron empleados distintos formatos y técnicas. Mientras que los retratos al óleo se destinaron a un público selecto, las virtudes de la reproductibilidad mecánica analizadas por Walter Benjamin sirvieron para llevar el rostro presidencial a las calles.

De tal suerte, retratos litográficos y también -al dar vuelta al siglo- fotográficos comenzaron a aparecer tanto en publicaciones oficiales como en la prensa periódica. Ambos se insertaron en una larga tradición retratística de los personajes de poder, cuyo nacimiento Peter Burke (2003) situó para la modernidad occidental en el siglo XVIII. 
Pero, asimismo, se hicieron parte de una forma simbólica más reciente, el retrato fotográfico burgués (Tagg 28-30), que en los países latinoamericanos había dado presencia visual e identidad social a las élites hasta mediados del siglo y paulatinamente, como en Europa, a los grupos sociales medios y populares, según han mostrado investigaciones en distintos países de la región (Navarrete; Massé). Los mandatarios chilenos, así, aparecen retratados como burgueses, con todas las convenciones del género. Una de las exigencias del mismo era mantener aquello que Carlos Reyero denomina como "una rigurosa caracterización figurativa" (110), asentando primero que todo las diferencias de género para evidenciar la distribución desequilibrada del poder.

En tanto epítome del proyecto nacional decimonónico, cada presidente posaba ante la cámara con la sobriedad, circunspección y seriedad que requería el cargo que en esos momentos investía, aunque también sabiendo que la suya no era una república de ciudadanos iguales. La imagen oficial, en tal sentido, obró como una herramienta discursiva poderosa y persuasiva. Hubo una confluencia entre el interés del Estado y el mercado editorial emergente por estampar y difundir la efigie del mandatario de turno. Durante las campañas electorales, tal interés se extendía a los candidatos que pugnaban por la silla presidencial. En términos generales, aquí hay elementos del "culto a la personalidad" que propició la cultura de masas en ciernes, tanto en países europeos como en Latinoamérica (Devés 26).

Dos canales complementarios, sumados a la prensa periódica, difundieron los retratos de las figuras de la alta política, ampliando la experiencia iconográfica de la gente común. Uno fue un tipo particular de publicaciones, los almanaques; el otro, la exposición de fotografías en las vitrinas de los estudios que se dedicaban a este oficio. Ubicados en las calles céntricas de Santiago y Valparaíso, no escatimaban recursos para dar a conocer sus adelantos técnicos y alto nivel de competencia en el nuevo arte de la imagen reproducida mecánicamente. Un aviso de El Chileno del 6 de junio de 1894, entre otros, informa: "En la vidriera de los señores Spencer i Compañía se exhibe un magnífico retrato de S. E. el Presidente de la República don Jorje Montt, en traje de gran uniforme con la banda presidencial cruzada al pecho" (3).

Muchas de las imágenes de la Lira Popular impresas aproximadamente entre 1890 y 1906 aluden a los mandatarios chilenos. Algunas de estas litografías y fotografías corresponden a los retratos oficiales de los presidentes o son muy cercanas a ellos en su factura (conciernen al personaje, pero parecen ser anteriores a su investidura) (fig. 8). Sin embargo, dada la variedad de fuentes visuales y herramientas gráficas conjugadas por la Lira Popular, los mismos personeros fueron llevados al papel en forma de xilografía. Es decir, los grabadores e impresores parecen haber tomado el modelo oficial para reinterpretarlo de acuerdo a los cánones de su propia labor estética, construida en base a los conocidos grabados en madera. De aquí el gran parecido que guardan muchas de estas nuevas apariciones presidenciales con sus modelos gráficos originales.

Esta reinterpretación puede apreciarse al contraponer las figuras 9 y 10, referidas a Germán Riesco Errázuriz, quien gobernara entre 1901 y 1906. Es difícil afirmar que 
FIGURA 8

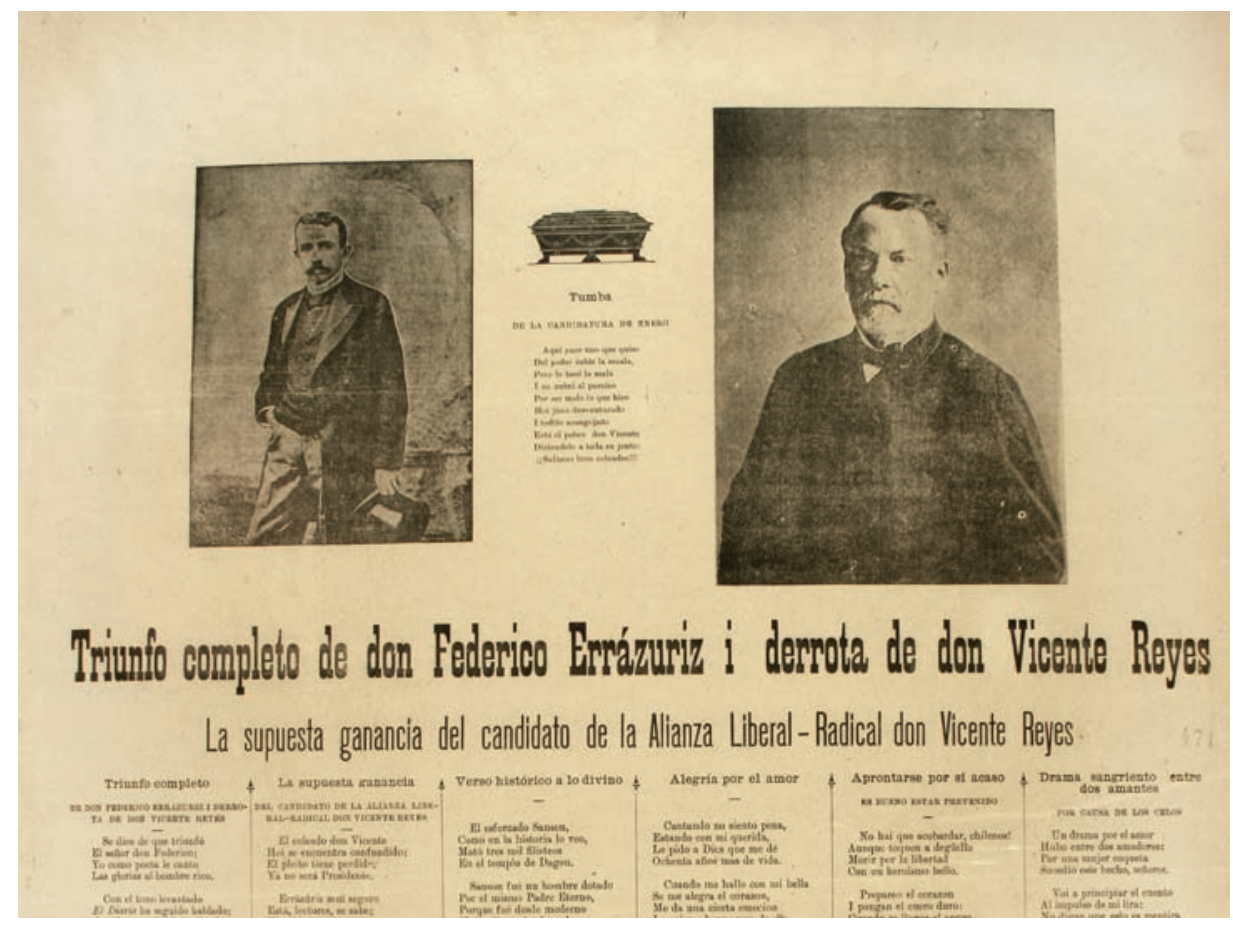

Retratos fotográficos en pliego de Daniel Meneses, Col. Lenz, vII, 34, 1896, detalle. A la izquierda, Federico Errázuriz, siguiendo el canon del retrato burgués, previo a su investidura. A la derecha, personaje sin identificar, representando (sin serlo efectivamente) al derrotado candidato Vicente Reyes.

quien ejecutó la xilografía haya tomado exactamente esta misma fotografía como modelo; tanto o más, si se considera que circularon en el país otros retratos de perfil del mismo personero. Independientemente de ello, hay elementos suficientes para establecer una semejanza entre ambas imágenes. Primero, la posición de perfil del sujeto, pose habitual en la práctica del retrato fotográfico del siglo xix, extendida a las primeras décadas de la centuria siguiente. La pose, según han advertido diversos estudiosos de los usos históricos de las imágenes, es un claro indicador de que se trata de una imagen construida, mediada tanto por los procesos fotomecánicos del aparato fotográfico, como por las convenciones -estéticas y sociales- y artificios del género en que esta imagen se inscribe (Burke 2001; Alvarado, Mege y Báez 2001). En este caso particular, el modo en que Riesco posó para el lente lo encuadra en los dominios del retrato burgués.

El contraste entre una y otra imagen entrega pistas valiosas sobre el proceso de recepción social de las efigies oficiales durante un período particular de la historia de Chile, signado por los extremos de la belle époque y la "cuestión social". En la xilografía se ha conservado más que la sola disposición proveniente del retrato. Algunos rasgos faciales son reconocibles en esta y aquella, en especial una barba espesa que cubre la 


\section{FIGURA 9}

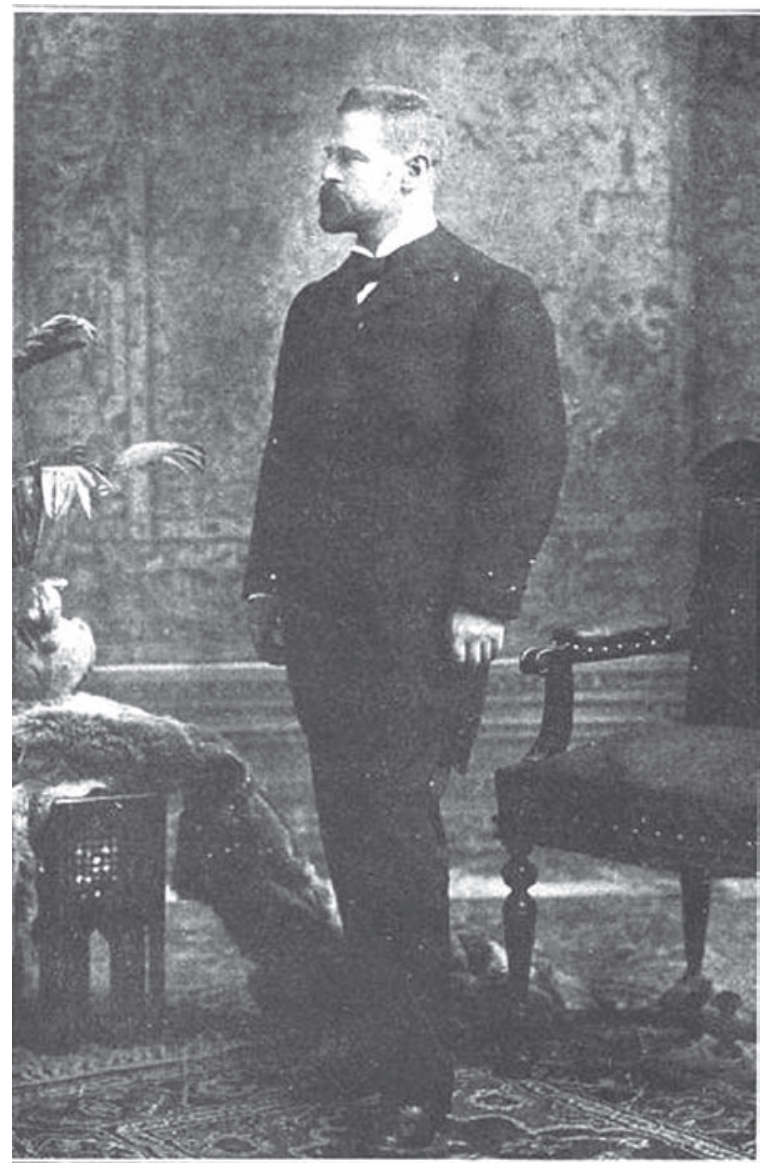

Izquierda: retrato fotográfico de Germán Riesco Errázuriz, Archivo Iconográfico Museo Histórico Nacional, c. 1900 . Abajo: xilografía sin título para Diálogo entre don Jerman Riesco i el rotito del norte tocante a los dueños de salitreras de Tarapacá, Col. A. A, 42 (det.).

\section{FIGURA 10}

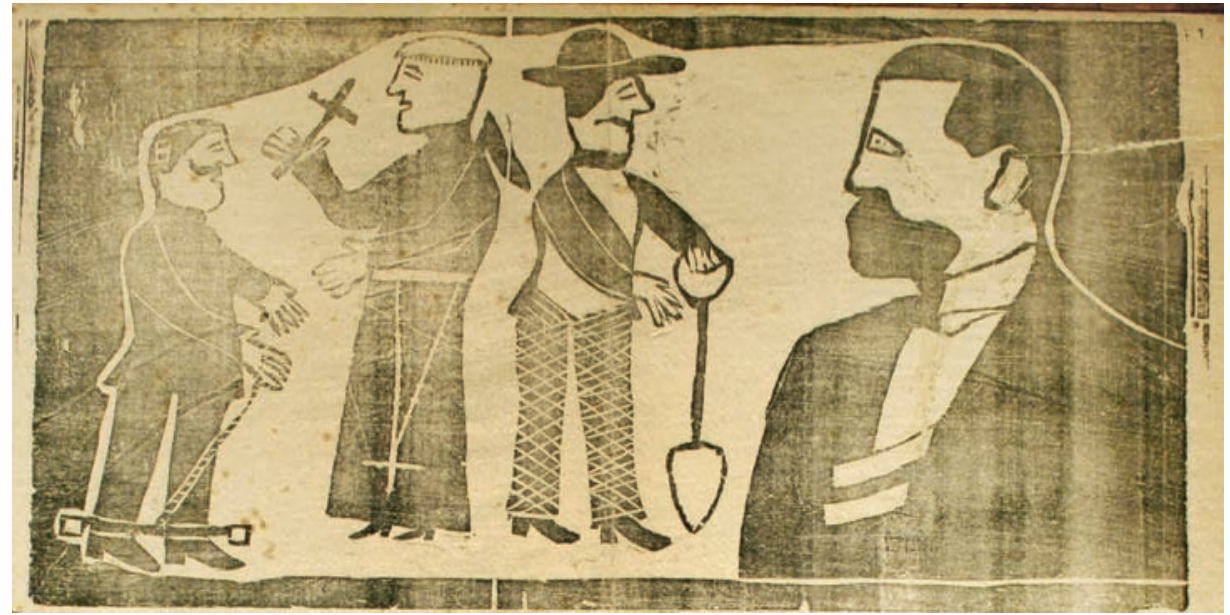


mitad de las mejillas. El trazo del grabado que dibuja el cabello corto y peinado se acerca también a la versión fotográfica. Más llamativa es la coincidencia en el traje que viste el sujeto. La imagen del pliego capta muy bien uno de los rasgos identitarios contenidos en las fotografías de los grupos dominantes, que junto con vestirlos, los enseñaba como miembros de un conglomerado social mayor (Corbin y Perrot 427). En este caso, quien realizó el grabado se preocupó de dar una seña puntual: la banda presidencial manifestaba a los espectadores-lectores inequívocamente la identidad del retratado. La preeminencia del mismo está reforzada por el tamaño relativo con que se lo situó en el pliego junto a los otros personajes (un hombre con grilletes y esposas, "condenado a muerte" y un sacerdote que lo acompaña; y el "rotito del norte", encarnación de un amplio espectro de la clase trabajadora chilena).

Un aspecto igualmente considerable, que propicia la delimitación entre las figuras, es la disposición corporal. Mientras que los tres personajes situados a la izquierda presentan brazos y manos separados del tronco, en ademán de movimiento, la figura que representa a Riesco está inmóvil. Esto supera el hecho de haberlo trazado sólo hasta la altura de los hombros, omitiendo los brazos. Es, con más propiedad, una correcta lectura de la forma en que los varones de la élite chilena buscaban proyectar su imagen pública, cuestión que se advierte ya en la fotografía de Riesco, donde la contención corporal refuerza la sobriedad de las ropas.

Ahora bien, considerada en el conjunto de la Lira Popular, la relación entre imagen y referente es contradictoria. Toda vez que se decidía incluir el rostro de un mandatario, se podía echar mano a distintos formatos. A falta de más documentación u otros testimonios de la época, es imposible determinar cuál era el criterio de decisión de los autores de los pliegos: disponer de una plancha con el retrato (fig. 11), encargar la imagen a un grabador en madera con suficiente antelación, etc.; pero como resultado, el proceso en que las imágenes intentan significar tal o cual presidente, varía su contenido de referencialidad. En este sentido, puede establecerse una escala que lleva las reinterpretaciones xilográficas de los retratos de los mandatarios hacia la constitución de un ícono. Aquello que parece ser una pérdida de detalles y matices o la creación de figuras esquemáticas apenas esbozadas por trazos blancos y negros resulta, por el contrario, un sistema iconográfico de alta efectividad. En el caso de la imagen del Presidente de la República, la caracterización del personaje cede lugar a la necesidad comunicativa de mostrar el cargo por él encarnado. Los atributos personales quedan supeditados a la representación de un hombre con traje que lleva una banda terciada, de manera tal que se desarticula el canon retratístico oficial. Es cuanto se aprecia en la figura 12.

El personaje de la izquierda representa al mismo Germán Riesco. El pliego celebra su reciente triunfo en las elecciones y comenta su programa de gobierno. El grabador anónimo que realizó esta xilografía trazó una barba tupida como principal rasgo facial del personaje. Es quizás la única seña que permite individualizarlo. Los otros elementos gráficos, entre los que destaca el traje oscuro y la corbata de moño 
FIGURA 11

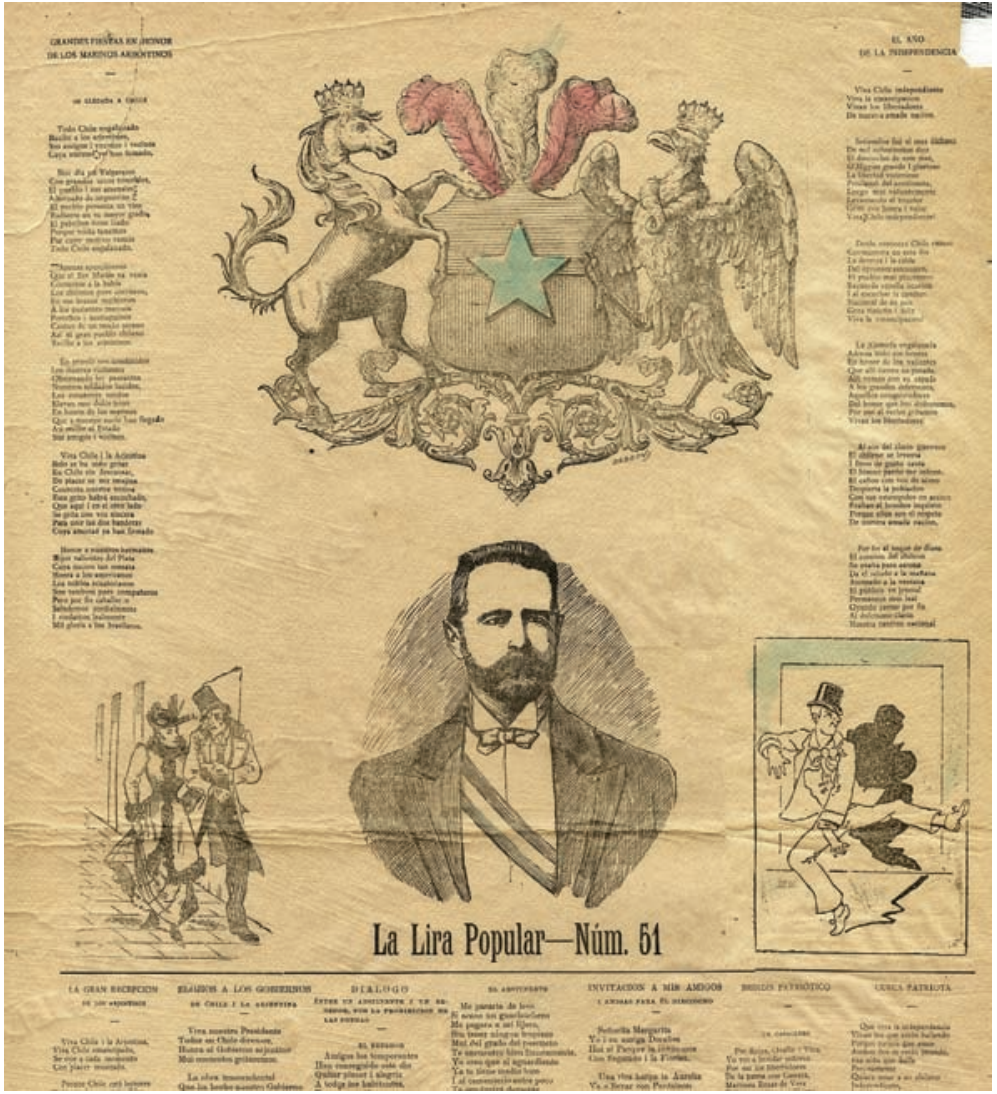

Col. A. A., 179 (detalle).

FIGURA 12

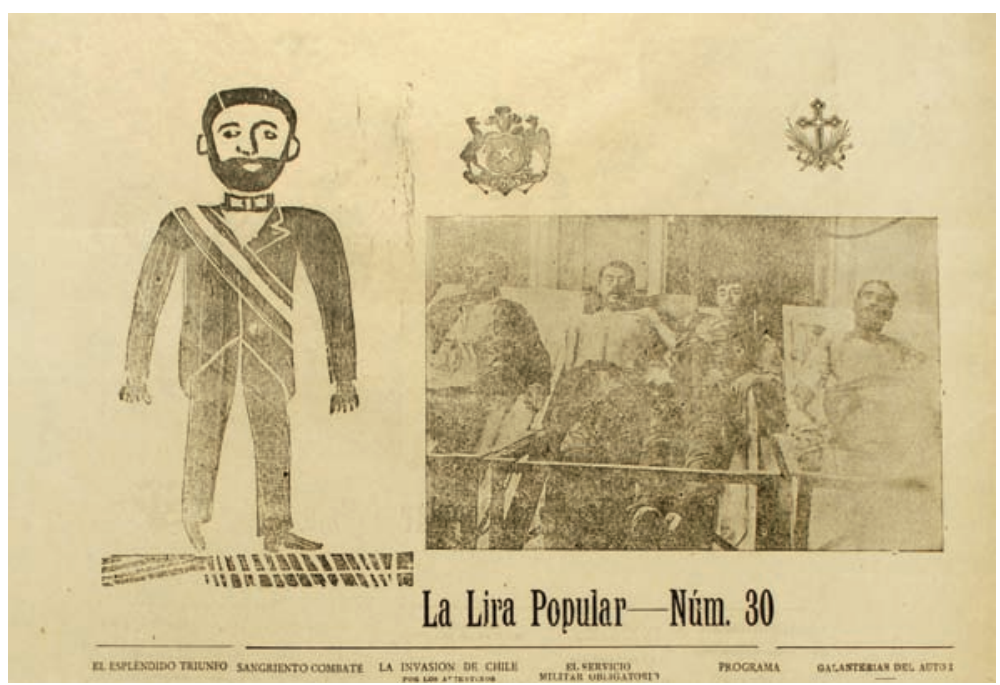

Col. A. A., 163 (detalle). 
sobre la pechera blanca, lo sitúan socialmente: es un varón de la élite, un caballero. Con todo, el factor decisivo en la construcción visual de la figura es la banda que lleva terciada, la que, a pesar de ser monocromática, alude certeramente a la enseña presidencial tricolor. Para el público receptor de la Lira Popular, el significado "Presidente de Chile" se expresaba y comprendía en la fórmula visual caballero + banda terciada ${ }^{1}$. Puede conjeturarse que la decodificación de un mensaje visual de tales características, vehiculado por un soporte gráfico que aunaba texto e imagen, era así condensado para un público con niveles variados y muchas veces precarios de alfabetización (entendiendo esta última como contacto cotidiano con los impresos, más que -de modo restrictivo- como habilidad lectoescritora).

\section{Conclusión}

Cabe hacer dos observaciones más para finalizar. Que en este último pliego se haya insertado una fotografía de cuatro hombres muertos -presumiblemente criminaleses en extremo interesante. Primero, porque pone en contacto a la personificación máxima del poder político de la república oligárquica (cuya dominación estaba respaldada por la fuerza, algo que no era un misterio para ningún contemporáneo) con su opuesto total, parte de aquello que algunos medios ilustrados denominaban "la hez de la plebe".

Segundo, porque los dos tipos de formatos visuales aquí yuxtapuestos mantienen con la realidad representada un vínculo propio. En el caso de la fotografía, se la consideraba un registro veraz de la realidad, aun cuando público y fotógrafos conocían los medios para alterar el resultado de las placas, de la misma manera en que eran conscientes de la preparación -en el sentido de arreglo y composición de objetos o sujetos a entrar en el encuadre- que implicaba cada toma. Una fotografía como la que aquí se observa tenía, para entonces, un significado distinto al que adquirió con el desarrollo de la prensa amarillista. El uso sistemático de fotografías en la prensa informativa nacional se inició, como quedó apuntado, en 1902, y en el caso de la revista ilustrada Sucesos de Valparaíso, el mismo año. Alboreando el siglo $\mathrm{xx}$, el "buen gusto" de los periódicos y magazines, tanto como la incapacidad para satisfacer la demanda por una mercancía visual de esta índole (falta de tecnología y fotógrafos competentes), no permitió que imágenes violentas como esta fuesen publicadas²; ni pensar en hacerlo en primera plana. Lo más probable es que la fotografía

1 En el caso excepcional de Jorge Montt (1891-1896), se lo podía particularizar con una gorra de almirante, además de la banda, como puede observarse en una xilografía en Col. Lenz, II, 15.

2 En cuanto hubo capacidad instalada, las empresas del rubro entraron de lleno a colmar esa demanda creada por sus propias publicaciones (y parangonándose con la circulación mundial de imágenes e informaciones sobre el fenómeno criminal), si bien estas decían ser misceláneas y abocarse a ser un escaparate de lo más granado de la sociedad. Cf. las páginas de Zig-Zag de 1910 en adelante. 
insertada en el pliego en cuestión haya estado destinada al archivo de la policía o a alguna publicación especializada y con circulación restringida, dependiente de esta misma institución.

Con todo, el estatuto de veracidad asignado al registro fotográfico parece haber entrado en juego al decidir incluir esta imagen en el pliego (Rodríguez-Plaza 93). Como objeto gráfico expuesto a la vista de sus potenciales usuarios, no pudo dejar de llamarles la atención, en tanto recurso para aumentar las ventas de una hoja que incluía el relato de un Sangriento combate entre bandidos i comisionados. Con respecto a la xilografía que la acompaña, su recepción debe haber sido bastante simple para un público urbano heterogéneo. Las xilografías podían conservar algunos componentes del retrato burgués -entre otros, la compostura y sobriedad del sujeto-, pero añadían un elemento gráfico de fácil lectura, que convierte la figura en aquello que pretende ser, un primer mandatario. Es un grabado en madera que no engaña a nadie. Le resulta imposible -a diferencia de la fotografía- escamotear su factura o dejar de remitir al artífice que le dio forma. Un grabado de tales características afirma representar a un personero en particular, pero apunta sobre todo a significar la función sociopolítica del Presidente de la República.

La desapropiación figurativa puede comprobarse en otros varios grabados en madera de traza semejante, tanto anteriores como posteriores a los aquí analizados (fig. 13). Hay algunos notables, como por ejemplo uno que corresponde a un pliego de 1890, en que una xilografía de trazos gruesos, que apenas esboza una figura humana, representa al presidente José Manuel Balmaceda (pliego firmado por Rosa Araneda, Col. Am., II, 288). Algunas hojas de poesía contemporáneas a esta incluyeron diversas imágenes de dicho mandatario, desde litografías académicas hasta reinterpretaciones de su retrato hechas en el formato característico de las xilografías de la Lira Popular (reproducidos en Navarrete 21 y 29). En esta imagen, las referencias al canon del retrato burgués no están presentes (más llamativo en el caso de Balmaceda, cuya efigie se ha documentado que circuló profusamente), pero incluso así el mensaje básico descansa en el hecho de ser un personaje masculino con una banda de tres franjas terciada sobre el pecho.

Se constata, así, la manera en que se constituyó un lenguaje visual peculiar que funciona en base a íconos. La versión xilográfica de los retratos presidenciales pasó a integrar un repertorio variado de grabados populares en madera que representan a los protagonistas preferidos de los versos de los cientos de pliegos hoy disponibles para examinar. Hubo íconos de minero, huaso, militar, cura, futre y borracho, ente otros. Esta manera de dar forma visual a la mezcla de realidad e imaginación que nutría los contenidos de los pliegos era funcional a las necesidades de puetas e impresores. Quienes creaban esta literatura de cordel dispusieron, por tanto, de una serie de matrices gráficas, movibles e intercambiables como los tipos con los que se formaban los textos, rápidamente adaptables a las noticias políticas o sociales que requerían "sacar versos" con gran prontitud. 
FIGURA 13

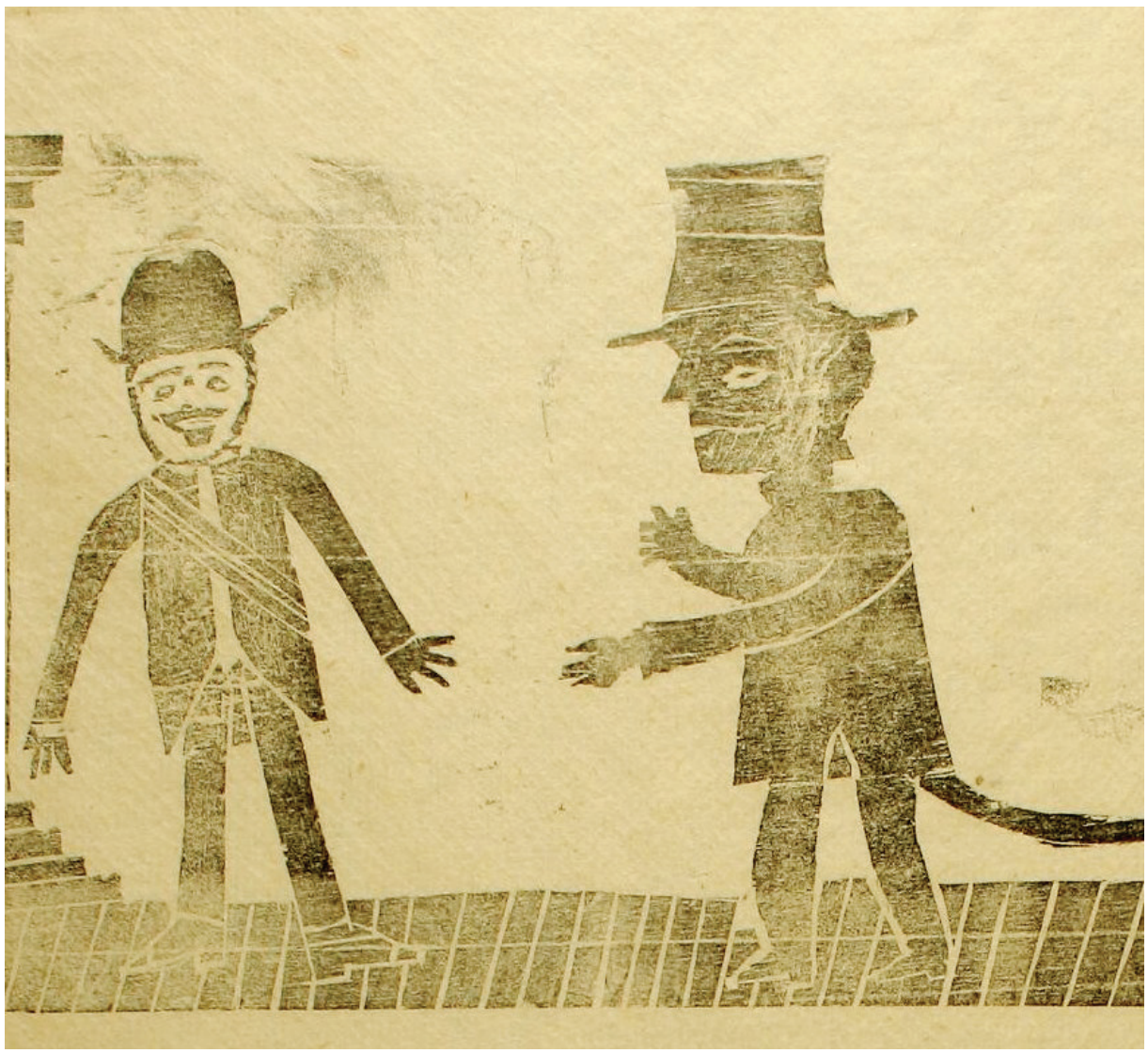

Col. A. A., 158 (detalle).

\section{Agradecimientos}

Las imágenes analizadas para elaborar el presente artículo y que aquí se reproducen provienen de las colecciones Rodolfo Lenz (Col. Lenz) y Alamiro de Ávila (Col. A. A.), conservadas por el Archivo de Literatura Oral y Tradiciones Populares de la Biblioteca Nacional de Chile. Agradezco a Soledad Abarca y Micaela Navarrete Araya, jefa y curadora, respectivamente, el acceso al material documental y su gentileza para compartir reproducciones digitales de los pliegos; agradecimiento que se extiende a Carolina Tapia, actual jefa de dicha repartición. Existe, como se sabe, un tercer acervo de este tipo de materiales, la Colección Amunátegui (Col. Am.), perteneciente al Archivo Central Andrés Bello de la Universidad de Chile, cuyos pliegos son de igual factura. 


\section{Referencias}

Acevedo Hernández, Antonio. Los cantores populares chilenos. Santiago: Nascimento, 1933. Impreso.

Alvarado, Margarita, Pedro Mege y Christian Báez, eds. Mapuche: fotografías siglos XIX y XX. Construcción y montaje de un imaginario. Santiago: Pehuén, 2001. Impreso.

Álvarez Caselli, Pedro. Historia del Diseño Gráfico en Chile. Santiago: Escuela de Diseño, Pontificia Universidad Católica de Chile, 2004. Impreso.

Anderson, Patricia. The Printed Image and the Transformation of Popular Culture. Oxford: Clarendon Press, 1994. Impreso.

Arias, Virginio. Memoria histórica de la Escuela de Bellas Artes de Santiago de Chile. Santiago: Imprenta Cervantes, 1908. Impreso.

Atria, Jorge Octavio. [Manuscritos sobre poetas populares]. Poetas populares en la sociedad chilena del siglo XIX: estudio filológico. Comp. Manuel Dannemann. Santiago: Archivo Central Andrés Bello, Universidad de Chile, 2004. 45-151. Impreso.

Benjamin, Walter. La obra de arte en la época de su reproductibilidad técnica [urtext]. México DF: Ítaca, 2003. Impreso.

Berríos, Pablo et al. Del taller a las aulas. La institución moderna del arte en Chile (1797-1910). Santiago: Departamento de Teoría e Historia del Arte, Universidad de Chile, 2009. Impreso.

Burke, Peter. Visto y no visto: el uso de la imagen como documento histórico. Barcelona: Crítica, 2001. Impreso.

---. La fabricación de Luis XIV. San Sebastián: Nerea, 2003. Impreso.

Corbin, Alain y Michelle Perrot. "El secreto del individuo". Historia de la vida privada, tomo 4. Dir. Philippe Ariès y Georges Duby. Madrid: Taurus, 1989. 425-468. Impreso.

Cornejo, Tomás. "Juan Bautista Peralta: cantor, poeta, periodista popular". Por historia y travesura. La Lira Popular del poeta Juan Bautista Peralta. Comp. Micaela Navarrete y Tomás Cornejo. Santiago: DiBAM, 2006. 23-34. Impreso.

De Ávila Martel, Alamiro. Diez grabados populares chilenos. Santiago: Universitaria, 1973. Impreso.

Desmadryl, Narciso. Galería nacional, o, Colección de biografías i retratos de hombres célebres de Chile. Santiago: Imprenta Chilena, 1854. Impreso.

Devés, Eduardo. "La cara de Balmaceda: fotografía, psicología y mentalidad”. La época de Balmaceda . Sergio Villalobos et al. Santiago: Centro de Investigaciones Diego Barros Arana, 1992. 23-40. Impreso.

Galí Boadella, Montserrat. Estampa popular, cultura popular. Puebla: Instituto de Ciencias Sociales y Humanidades Alfonso Vélez Pliego, Benemérita Universidad Autónoma de Puebla, 2007. Impreso. 
Gretton, Thomas. "De cómo fueron hechos los grabados de Posada". Posada y la prensa ilustrada: signos de modernización y resistencias. VV.AA. México DF: INBA, 1996. 121-149. Impreso.

Lenz, Rodolfo. "Sobre la poesía popular impresa de Santiago de Chile. Contribución al Folklore Chileno”. Anales de la Universidad de Chile, Memorias científicas y literarias 144 (1919) [1895]: 510-622. Impreso.

Malacchini, Simoné. Lira Popular. Identidad gráfica de un medio impreso chileno. Santiago: Ocho Libros, 2015. Impreso.

Massé, Patricia. Simulacro y elegancia en tarjetas de visita. Fotografías de Cruces y Campa. México DF: INAH, 1998. Impreso.

Millar, Pedro. "La Lira Popular y la tradición chilena del grabado en madera”. Revista de Arte uC 6 (1990): 17-21. Impreso.

Navarrete, José Antonio. Las buenas maneras. Fotografía y sujeto burgués en América Latina (siglo xIx). Aisthesis 35 (2002): 11-16. Impreso.

Navarrete, Micaela. Balmaceda en la poesía popular 1886-1896. Santiago: Centro de Investigaciones Diego Barros Arana, 1993. Impreso.

Oficina Central de Estadística. Sétimo Censo Jeneral de la Población de Chile levantado el 28 de noviembre de 1895, tomo II. Santiago: Imprenta del Universo de Guillermo Helfmann, 1902. Impreso.

Orellana, Marcela. Lira popular. Pueblo, poesía y ciudad en Chile (1860-1976). Santiago: Universidad de Santiago de Chile, 2005. Impreso.

Ossandón, Carlos y Eduardo Santa Cruz. Entre las alas y el plomo. La gestación de la prensa moderna en Chile. Santiago: Lom, 2001. Impreso.

---. El estallido de las formas. Chile en los albores de la 'cultura de masas'. Santiago: Lom, 2005. Impreso.

Poirier, Eduardo. Chile en 1910. Edición del Centenario de la Independencia. Santiago: Imprenta Barcelona, 1910. Impreso.

Reyero, Carlos. Apariencia e identidad masculina. De la Ilustración al Decadentismo. Madrid: Cátedra, 1999. Impreso.

Rodríguez-Plaza, Patricio. "Imágenes, fotografía e identidad desde la Lira Popular". Aisthesis 35 (2002): 89-100. Impreso.

Salinas, Maximiliano, Daniel Palma, Christian Báez y Marina Donoso. El que ríe último... Caricaturas y poesías en la prensa humorística chilena del siglo XIX. Santiago: Universitaria/Centro de Investigaciones Diego Barros Arana, 2001. Impreso.

Salinas, Maximiliano, Tomás Cornejo y Catalina Saldaña. ¿Quiénes fueron los vencedores? Elite, pueblo y prensa humorística de la Guerra Civil de 1891. Santiago: Centro de Investigaciones Diego Barros Arana/Lom, 2005. Impreso.

Soto Veragua, Jorge. Historia de la imprenta en Chile. Desde el siglo XVIII al XXI. Santiago: Árbol Azul, 2009. Impreso.

Subercaseaux, Bernardo. Fin de siglo. La época de Balmaceda. Modernización y cultura en Chile. Santiago: Aconcagua, 1988. Impreso. 
Tagg, John. El peso de la representación. Ensayos sobre fotografías e historias. Barcelona: Gustavo Gili, 2005. Impreso.

Tapia, Carolina. "Grabado popular: ¿antecedente o referente en la historia del grabado en Chile?”. Mapocho 72 (2012): 79-94. Impreso.

Tornero, Recaredo. Chile Ilustrado. Guía descriptivo[sic] del territorio de Chile, de las capitales de provincia, $i$ de los puertos principales. Valparaíso: Librerías y Agencias del Mercurio, 1872. Impreso.

XVI Seminario sobre patrimonio cultural. Del cordel a las redes sociales. Santiago: DIBAM, 2015. Impreso.

Recibido: 19 mayo 2015

Aceptado: 18 marzo 2016 